\title{
Emotional dimensions in people with aggressive behavior: differential responses to affective visual stimuli
}

\author{
Dimensões emocionais em pessoas com comportamento agressivo: \\ diferentes respostas a estímulos visuais
}

\author{
Carlos Gantiva, ${ }^{1}$ Erwin Estupiñan, ${ }^{1}$ Ingrid Montaña, ${ }^{1}$ María Sierra, ${ }^{1}$ Eva Zocadegui, ${ }^{1}$ Tania Romo-González ${ }^{2}$
}

\begin{abstract}
Introduction: The emotional interaction between personal attributes and the environment is a key element to understand aggression. This study identified emotional responses of people with different aggressive traits to pictures with a specific affective content.

Methods: Three hundred fifteen individuals were divided into five groups according to their scores on the Buss-Perry Aggression Questionnaire, which consists of 24 pictures of the International Affective Picture System that depict aggression, the suffering of others, filial situations, and sexual content. Each picture was evaluated for valence, arousal, and dominance using the Self-Assessment Manikin scale.

Results: Sexual pictures were more appetitive and associated with more arousal in the groups of individuals with some aggression-related dimension than in the non-aggressive group. Conclusions: A strong interaction was found between aggressive traits (e.g., verbal aggression, physical aggression, anger, and hostility) and pictures with a sexual content. This interaction is decisive in understanding the later phases of aggressive behaviors and sexual aggression.
\end{abstract}

Keywords: Emotions, aggression, motivation, sexual violence, arousal.

\section{Resumo}

Introdução: A interação emocional entre atributos pessoais e o ambiente é um elemento fundamental para o entendimento da agressão. O objetivo deste estudo é identificar as respostas emocionais de pessoas com diferentes traços de agressividade para a exposição a figuras com conteúdo afetivo diverso.

Métodos: Trezentos e quinze indivíduos foram divididos em cinco grupos de acordo com seus resultados no questionário Buss-Perry Aggression Questionnaire, que consiste de 24 figuras do Sistema Internacional de Figuras com Conteúdo Emocional, mostrando agressão, sofrimento alheio, cenas entre pais e filhos e com conteúdo sexual. Cada figura foi avaliada quanto às dimensões de prazer, alerta e dominância usando a escala SelfAssessment Manikin.

Resultados: As figuras com conteúdo sexual foram mais apetitivas, e foram relacionadas a maior reposta de alerta nos grupos de indivíduos com alguma dimensão associada à agressão quando comparados ao grupo não agressivo.

Conclusões: Encontrou-se uma forte interação entre traços agressivos (e.g., agressão verbal, agressão física, raiva e hostilidade) e figuras com conteúdo sexual. Essa interação é decisiva para o entendimento das fases tardias dos comportamentos agressivos e a agressão sexual.

Descritores: Emoções, agressão, motivação, violência sexual, alerta.

\footnotetext{
${ }^{1}$ Department of Psychology, University of San Buenaventura, Bogota, Colombia. ${ }^{2}$ Integrative Health and Biology Area, Instituto de Investigaciones Biológicas, Universidad Veracruzana, Xalapa, Mexico.

Financial support: none.

Submitted Mar 02 2014, accepted for publication Jun 27 2014. No conflicts of interest declared concerning the publication of this article.

Suggested citation: Gantiva C, Estupiñan E, Montaña I, Sierra M, Zocadegui E, Romo-González T. Emotional dimensions in people with aggressive behavior: differential responses to affective visual stimuli. Trends Psychiatry Psychother. 2014;36(4):203-208. http://dx.doi.org/10.1590/2237-6089-2014-0004
} 


\section{Introduction}

Aggression has traditionally been conceptualized as either an impulsive act that is motivated by anger or a premeditated behavior that is oriented toward achieving goals. However, this dichotomy is incomplete because it addresses aggressive behavior only from the perspective of the individual. ${ }^{1-3}$ In contrast to this view, the general aggression model (GAM) defines aggression as a complex interaction between inputs (personal attributes and circumstances), mediating pathways (cognition, affect, and arousal), and outcomes (decisions and actions). ${ }^{4}$ In this sense, it is the interaction between the individual and environmental variables that causes aggression. ${ }^{5}$

Emotions and emotional regulation are key elements of the second phase of GAM. Emotions are action dispositions, in which one of the primary motivational systems is activated: the appetitive system associated with approach behaviors and the defensive system associated with avoidance behaviors. ${ }^{6}$

Emotional experiences may be organized into three dimensions: valence, arousal, and dominance. Valence determines the activation of one of the primary motivational systems and refers to the evaluation of stimuli as pleasant or unpleasant. Stimuli that are evaluated as pleasant activate the appetitive motivational system, and stimuli that are evaluated as unpleasant activate the defensive system. ${ }^{7}$ This dimension has a neurophysiological substrate that determines its bipolar character and primacy over the other two dimensions. ${ }^{6}$ Arousal refers to the energy invested in emotion and does not have a separate neurophysiological substrate. Thus, arousal is the intensity of the emotional experience. ${ }^{8}$ The third dimension, dominance, explains the degree of control over the perceived emotional response and implies the interruption or continuity of the behavioral response. This dimension originates in more evolutionarily recent structures of the human brain, and its function includes inhibition, delaying, evaluation of the context, and planning. ${ }^{9}$

Moreover, emotional regulation allows the individual to restrain emotion and direct behavior toward achieving goals while emotion takes its course. ${ }^{10}$ Aggressive behavior has two styles of maladaptive emotional regulation: under-regulation and over-regulation. Under-regulation occurs when the individual fails to contain the emotional response and inhibit impulsive behavior. ${ }^{5}$ Over-regulation occurs when emotion is not allowed to take its course; instead, the individual stops its course by means of avoidance or suppression of the emotional experience. ${ }^{11}$

Evidence has demonstrated the role of emotional regulation in aggression, ${ }^{12-15}$ but the interaction between personal attributes and circumstances (i.e., the two elements of the first phase of GAM) is less known. For example, subjects with high scores in psychoticism/ aggressiveness evaluate violent erotic stimuli as more erotic than subjects with low scores, ${ }^{16}$ but no research has been conducted on emotional responsiveness in aggressive people while they observe stimuli with different affective social content, either pleasant (sexual or filial situations) or unpleasant (aggression and suffering of others). This study analyzed the effect of the interaction between different components of aggression and stimuli with different affective social content on emotional responses.

\section{Methods}

\section{Participants}

Three hundred fifteen participants (158 men and 157 women), 18 to 26 years old (mean \pm standard deviation $=22.41 \pm 3.26$ ), were included in the study. The participants were recruited from different areas through public announcements in Bogotá, Colombia. They were distributed into five groups according to scores obtained on the Buss-Perry Aggression Questionnaire (BPAQ), with the purpose of identifying people with different dimensions of aggressive behaviors. The aggressive group included participants whose score was above the 70th percentile in one of the scales of the BPAQ (i.e., physical aggression, verbal aggression, anger, and hostility). The control group included participants whose score was below the 60th percentile in any of the scales. The inclusion criterion was completion of at least high school, and participants with mental illness or visual deficits were excluded.

The aggressive group was distributed into the following groups: physical aggression ( $n=62$ ), verbal aggression $(n=64)$, anger $(n=63)$, and hostility $(n=64)$. A control group was included for comparisons $(n=62)$.

\section{Measures and instruments}

\section{Aggression}

The BPAQ ${ }^{17}$ was used to measure different dimensions of aggressive behavior. The instrument was administered to the participants using an adapted Spanish version. ${ }^{18}$ The questionnaire comprises 29 items and has a fourfactor structure: physical aggression, verbal aggression, anger, and hostility. The BPAQ had high internal consistency, with Cronbach's alpha $(\alpha)$ values of 0.86 for physical aggression, 0.68 for verbal aggression, 0.77 for anger, and 0.72 for hostility. ${ }^{18}$ 


\section{Pictures with different emotional content}

Twenty-four pictures from the International Affective Picture System (IAPS) ${ }^{19}$ were used. All pictures were validated in Colombia (IAPS picture codes: 1350, 6520, 5726, 8208, 4616, 9163, 7026, 2155, 7021, 4668, 7077, 6315, 7161, 2095, 7236, 9413, 7405, 4693, 7033, 2299, 7255, 2375.1, 8475, and 4622). ${ }^{9}$ The IAPS is an instrument with more than 1000 color pictures that cover different areas (e.g., sports, sex, violence, animals, family, etc.) and elicit different emotional responses in different cultures and countries. ${ }^{9,19}$ The pictures chosen for the present study were distributed into four categories: aggression, suffering of others, filial, and sexual. The first two categories were chosen because they are directly associated with aggressive behaviors and were considered aversive during the validation process in Colombia. The filial and sexual image categories were chosen because they are inversely associated with aggressive behaviors, as their content is appetitive and pro-social.

\section{Emotional dimensions}

The Self-Assessment Manikin (SAM) ${ }^{19}$ was used to measure the three dimensions of emotion: valence, arousal, and dominance. The SAM consists of three pictographic scales, each with five humanoid figures that are distributed along a continuum in which the three dimensions of emotion are represented: valence (agreeable/disagreeable), arousal (relaxed/activated), and dominance (dominant/dominated). The valence rating ranges from a figure with a large smile (score of 9 , very pleasant) to a figure with a pronounced frown (score of 1 , very unpleasant).

The arousal rating ranges from a figure that appears agitated (score of 9, high arousal) to a figure that looks drowsy (score of 1 , low arousal). The dominance rating ranges from a very large figure (score of 9, high dominance) to a very small figure (score of 1 , low dominance).

\section{Procedure}

The experiment was conducted in a dimly lit laboratory with comfortable desks that were placed in rows in front of a slide projection screen. A computerprojector system controlled the timing of the stimulus presentation. No more than 20 subjects performed the test simultaneously. Each rating trial began with a preparation slide ("Get ready to rate the next image") that lasted $5 \mathrm{~s}$, followed by an observation period of $6 \mathrm{~s}$. During the next $15 \mathrm{~s}$, the participants were asked to rate the picture along the dimensions of valence, arousal, and dominance using the SAM scales.

All pictures were in color and measured $120 \mathrm{~cm}$. The participants assessed all 24 pictures during the experimental session. The ratings for the first five pictures were considered a practice session and not included in the analyses. The sequential order of the pictures was randomized, with the constraint that a given category could not be displayed consecutively more than twice.

All of the participants provided written informed consent to participate in the study. The study protocol was approved by the Ethics Committee of the University of San Buenaventura.

\section{Data analysis}

To identify the primary motivational system that was activated by each picture category according to the scores on the BPAQ, we used a scatter diagram, with valence (appetitive/aversive) on the $y$-axis and arousal (low/high) on the x-axis. To analyze the effect of the participants' aggressive characteristics on the evaluation of the pictures with a different affective content, a mixed $4 \times 5 \times 2$ analysis of variance (ANOVA) was used for each dimension of emotion, with Picture (aggression, suffering of others, filial, and sexual) as the withinsubjects factor and Group (physical aggression, verbal aggression, anger, hostility, and control) and Sex as the between-subjects factors. When the assumption of sphericity was not met, Greenhouse-Geisser correction was applied to the degrees of freedom in all cases. Posthoc analyses of the mean values were performed using paired multiple comparisons, adjusted with Bonferroni correction. The level of significance was $p<0.05$. The partial eta squared $\left(n_{p}{ }^{2}\right)$ is also presented. All of the statistical analyses were performed using the Statistical Package for the Social Sciences (SPSS) 20.0 software.

\section{Results}

\section{Distribution of IAPS pictures according to BPAQ factors}

Figure 1 shows the distribution of the 24 pictures of the IAPS in the two-dimensional affective space composed of the valence and arousal dimensions. The groups with a significant score on the BPAQ scales situated the pictures with filial and sexual content on the positive pole, indicating that the pictures were very appetitive and highly arousing, whereas the pictures of aggression and suffering of others were on the negative pole, indicating that the pictures were aversive and moderately arousing. These results were similar to those found for the control group, except that this group evaluated the pictures with sexual content as being the least appetitive and less arousing. 


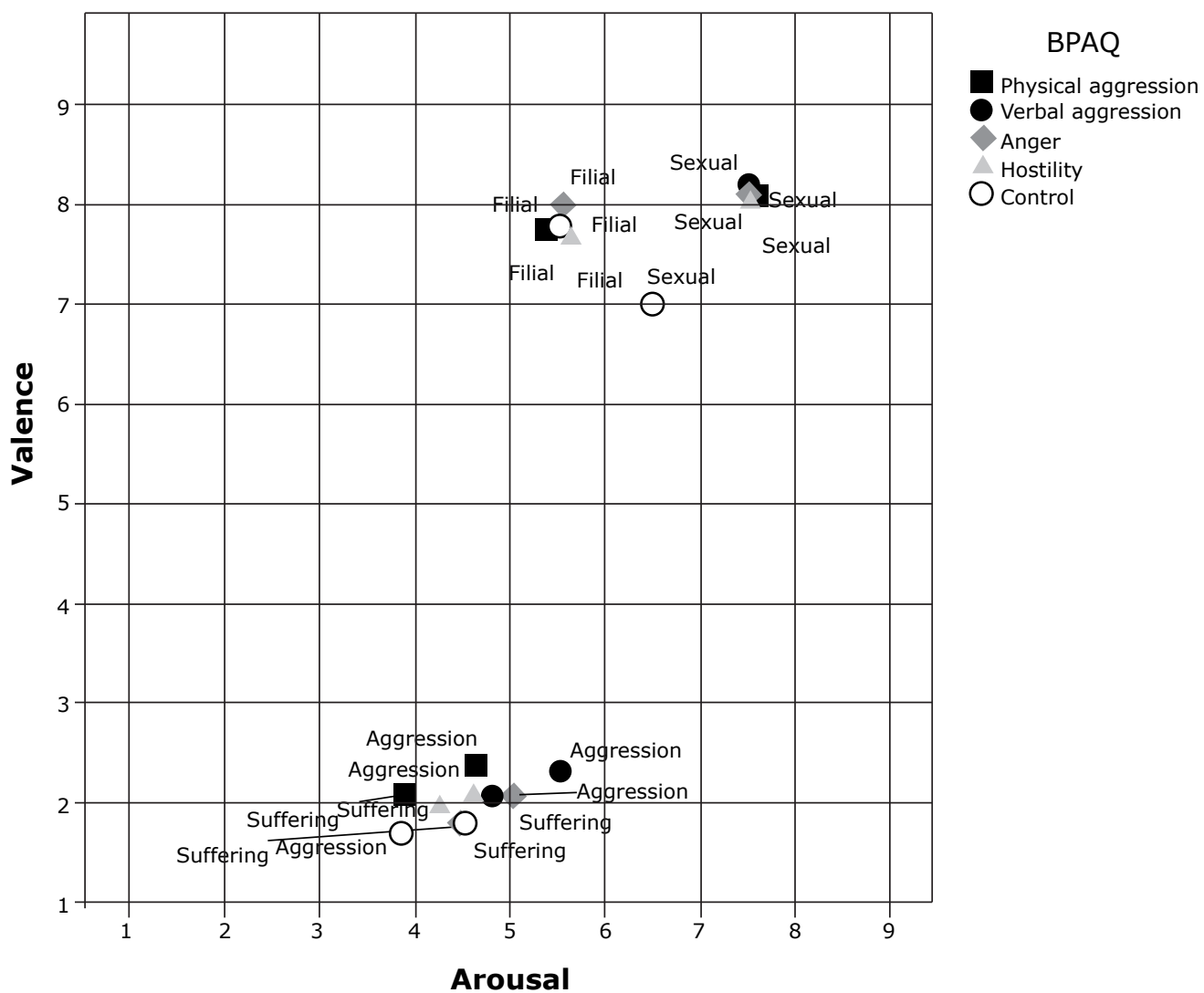

Figure 1 - Picture distribution according to Buss-Perry Aggression Questionnaire (BPAQ) scores.

To assess the relationship between the dimensions of emotion for each picture and the scores on the BPAQ in each of the groups, a Pearson correlation was performed. The scores in the verbal aggression group were positively correlated with valence in the case of suffering of others $(r=0.37, p=0.04)$. The scores in the hostility group were negatively correlated with arousal in the case of filial pictures $(r=-0.39, p=0.01)$ and negatively correlated with valence and arousal in the case of sexual pictures $(r$ $=-0.34, p=0.04$, and $r=-0.33, p=0.04$, respectively).

\section{Valence}

The ANOVA of the valence dimension revealed a significant main effect of Picture $\left(F_{3,51}=1184.17, p<\right.$ $\left.0.001, \eta_{p}{ }^{2}=0.87\right)$. The pictures of suffering of others were the most aversive (all $p<0.01$ ), followed by the aggression pictures (all $p<0.01$ ). The sexual pictures were the most appetitive (all $p<0.01$ ), followed by the filial pictures (all $p<0.01$ ). No significant differences were found between sexual and filial pictures $(p=1)$. A significant Picture $\times$ Group interaction was found $\left(F_{4,17}=\right.$ $\left.4.02, p<0.001, \eta_{p}{ }^{2}=0.08\right)$. The control group evaluated the sexual pictures as significantly less appetitive than all the other groups (Table 1 ). The Picture $\times$ Group $\times$ Sex interaction was not significant $(p>0.1)$.

\section{Arousal}

The ANOVA of arousal ratings revealed a significant main effect of Picture $\left(F_{3,51}=75.67, p<0.001, \eta_{p}{ }^{2}=\right.$ $0.30)$. The sexual pictures were evaluated as more arousing than the suffering of others, filial and aggression pictures (all $p<0.001$ ). The pictures of suffering of

Table 1 - Means \pm standard deviation of valence for all picture categories in each group

\begin{tabular}{lcccc} 
& \multicolumn{5}{c}{ picture categories in each group } \\
\cline { 2 - 5 } Group & Aggression & $\begin{array}{c}\text { Suffering } \\
\text { of others }\end{array}$ & Filial & Sexual \\
\hline $\begin{array}{l}\text { Physical } \\
\text { aggression }\end{array}$ & $2.43 \pm 1.35$ & $2.09 \pm 1.36$ & $7.78 \pm 1.28$ & $8.08 \pm 1.47$ \\
Verbal & $2.36 \pm 1.18$ & $2.05 \pm 1.18$ & $7.81 \pm 1.30$ & $8.20 \pm 1.42$ \\
aggression & & & & \\
Anger & $2.11 \pm 1.18$ & $1.78 \pm 1.16$ & $7.99 \pm 1.18$ & $8.07 \pm 1.35$ \\
Hostility & 2.091 .27 & $1.94 \pm 1.20$ & $7.72 \pm 1.21$ & $8.01 \pm 1.32$ \\
Control & $1.91 \pm 1.34$ & $1.74 \pm 0.96$ & $7.88 \pm 0.94$ & $7.00 \pm 1.32 *$ \\
\hline p $<0.05$. & & & &
\end{tabular}


Table 2 - Means \pm standard deviation of arousal for all picture categories in each group

\begin{tabular}{lcccc}
\hline & \multicolumn{4}{c}{ Picture category } \\
\cline { 2 - 5 } Group & Aggression & $\begin{array}{c}\text { Suffering } \\
\text { of others }\end{array}$ & Filial & Sexual \\
\hline $\begin{array}{l}\text { Physical } \\
\text { aggression }\end{array}$ & $4.69 \pm 2.36$ & $3.89 \pm 2.55$ & $5.40 \pm 2.29$ & $7.59 \pm 1.44$ \\
$\begin{array}{l}\text { Verbal } \\
\text { aggression }\end{array}$ & $5.62 \pm 2.25$ & $4.90 \pm 2.51$ & $5.60 \pm 2.13$ & $7.51 \pm 1.27$ \\
$\begin{array}{l}\text { Anger } \\
\text { Hostility }\end{array}$ & $5.14 \pm 2.56$ & $4.53 \pm 2.68$ & $5.61 \pm 2.43$ & $7.51 \pm 1.70$ \\
$\begin{array}{l}\text { Control } \\
\text { group }\end{array}$ & $4.70 \pm 2.34$ & $3.87 \pm 2.30$ & $5.65 \pm 1.96$ & $6.64 \pm 1.72 *$ \\
$* p=0.05$. & & $4.27 \pm 2.88$ & $5.69 \pm 2.24$ & $7.54 \pm 1.54$ \\
\hline$p=0.43$ & & & & \\
\hline
\end{tabular}

others were evaluated as less arousing (all $p<0.001$ ). A significant Picture $\times$ Group interaction was found $\left(\mathrm{F}_{4,17}=\right.$ 2.16, $\left.p=0.07, \eta_{p}^{2}=0.04\right)$. The control group evaluated the sexual pictures as less arousing than the physical aggression group (Table 2). The Picture $\times$ Group $\times$ Sex interaction was not significant $(p>0.1)$.

\section{Dominance}

The ANOVA of dominance ratings revealed a significant main effect of Picture $\left(F_{3,51}=121.43, p<0.001, \eta_{p}{ }^{2}\right.$ $=0.41)$. Pleasant pictures had the highest dominance ratings, in which sexual pictures $(6.65 \pm 0.16)$ had higher dominance ratings than filial pictures $(6.15 \pm 0.12 ; \mathrm{p}=$ $0.02)$. The dominance ratings for aggression pictures $(4.11 \pm 0.14)$ were higher than those for pictures of suffering of others $(3.32 \pm 0.15 ; p<0.001)$. The Picture $x$ Group interaction and Picture $\times$ Group $\times$ Sex interaction were not significant (all $p>0.1$ ).

\section{Discussion}

This study analyzed the effect of the interaction between components of aggressiveness and stimuli with different affective contents on emotional responsiveness. The evaluation of valence and arousal was similar to that found in previous observations in different populations and countries. ${ }^{9,19-21}$ However, significant differences were found in the evaluations of the sexual pictures according to different attributes of aggressive behaviors. Sexual pictures were rated as significantly more appetitive and more arousing by the aggressive groups than by participants who did not present any component of aggressive behaviors.

Similar results in a study about aggressive personality traits were reported by Reuter et al., ${ }^{16}$ who found that people with higher scores in psychoticism/ aggressiveness rated violent erotic stimuli as more erotic and interesting than subjects with lower scores. Eysenck ${ }^{22}$ found that people with higher scores on the psychoticism scale of the Eysenck Personality Questionnaire (EPQ) ${ }^{23}$ are more interested in aggressive sex than people with lower psychoticism scores. Therefore, aggressive people appear to have a major emotional response to sexual stimuli that predisposes them to their sexual behavior.

In contrast to findings reported by Reuter et al. ${ }^{16}$ and Eysenck, ${ }^{22}$ our results showed a significant difference in valence and arousal, although the sexual pictures did not have an aggressive content, which suggests that people with aggressive characteristics have a more intense emotional response to sexual stimuli and rate them as having greater positive valence in general. This suggests an association between sex and aggression, which may be explained by the effect of higher testosterone levels and lower cortisol levels in people with increasing levels of aggressiveness and sexual desire. ${ }^{24-27}$

According to GAM, aggressive behaviors occur not only within an individual but also in relation to the context. Our results showed a strong interaction between aggressive traits (personal attributes, such as verbal aggression, physical aggression, anger, and hostility) and environments with a sexual content, in which emotional regulation in response to sexual stimuli changed in the aggressive groups. This interaction contributes to an understanding of sexual aggression, in which sexual offenders exhibit high pleasure and arousal in an environment with a sexual content and are unable to control it. 5,28 This deficit in emotional self-regulation may be attributable to a process of under-regulation.

To corroborate these findings, future studies should assess emotional responses in people with aggressive traits by measuring modulation of the startle reflex, heart rate, and galvanic skin response. The use of these measures may provide a more objective explanation for our results and provide empirical evidence of the association between aggression and sexual content in the environment, which may lead to a better understanding of behaviors associated with sexual assault.

\section{References}

1. Duxbury J. An evaluation of staff and patient views of and strategies employed to manage inpatient aggression and violence on one mental health unit: a pluralistic design. J Psychiatr Ment Health Nurs. 2002;9:325-37.

2. Paterson B, Bowie V, Miller G, Leadbetter D. Reframing the problem of violence towards mental health nurses: a work in progress. Int J Soc Psychiatry. 2010;56:310-20.

3. Sutton D, Wilson M, Van Kessel K, Vanderpyl J. Optimizing arousal to manage aggression: a pilot study of sensory modulation. Int J Ment Health Nurs. 2013;22:500-11. Epub 2013 Feb 3.

4. Anderson CA, Bushman BJ. Human aggression. Annu Rev Psychol. 2002;53:27-51.

5. Roberton T, Daffern M, Bucks RS. Emotional regulation and aggression. Aggress Violent Behav. 2012;17:72-82. 
6. Lang PJ. Emotion and motivation: toward consensus definitions and a common research purpose. Emot Rev. 2010;2:229-33.

7. Bradley M, Lang P. Emotion and motivation. In: Cacioppo J, Tassinary LG, Berntson GG, editors. The Handbook of Psychophysiology. 3rd ed. New York: Cambridge University Press; 2007.

8. Bradley MM. Natural selective attention: orienting and emotion. Psychophysiology. 2009;46:1-11. Epub 2008 Sep 5.

9. Gantiva C, Guerra P, Vila J. Validación colombiana del sistema internacional de imágenes afectivas: evidencias del origen transcultural de la emoción. Act Colom Psicol. 2011;14:103-11.

10. Gratz KL, Tull MT. Emotion regulation as a mechanism of change in acceptance- and mindfulness-based treatments. In: Baer $\mathrm{R}$, editor. Assessing mindfulness and acceptance: Illuminating the processes of change. Oakland: New Harbinger Publications; 2010.

11. Kashdan TB, Barrios V, Forsyth JP, Steger MF. Experiential avoidance as a generalized psychological vulnerability: comparisons with coping and emotion regulation strategies. Behav Res Ther. 2006;44:1301-20.

12. Joyce CJ, Dillane J, Vasquez EA. The role of anger in offending: a grounded theory analysis of mentally disordered patients. J Forens Psychiatry Psychol. 2013;24:247-68.

13. Norström T, Pape H. Alcohol, suppressed anger and violence. Addiction. 2010;105:1580-6. Epub 2010 Jun 21.

14. Sullivan TN, Helms SW, Kliewer W, Goodman KL. Associations between Sadness and Anger Regulation Coping, Emotional Expression, and Physical and Relational Aggression among Urban Adolescents. Soc Dev. 2010;19:30-51.

15. Wilkowski BM, Robinson MD. The anatomy of anger: an integrative cognitive model of trait anger and reactive aggression. Pers Individ Dif. 2010;78:9-38.

16. Reuter $M$, Netter $P$, Janke $W$. Personality and reciprocal inhibition theory: the link between aggression and sexual reactivity. Pers Individ Dif. 2003;35:1765-82.

17. Buss $\mathrm{AH}$, Perry M. The aggression questionnaire. J Pers Soc Psychol. 1992;63:452-9.

18. Andreu-Rodríguez JM, Peña-Fernández ME, Graña-Giómez JL. Adaptación psicométrica de la versión española del cuestionario de agresión. Psicothema. 2002;14:476-82.

19. Lang PJ, Bradley MM, Cuthbert BN. International affective picture system (IAPS): affective ratings of pictures and instruction manual. Technical Report A-8. Gainesville: University of Florida; 2008.
20. Dufey M, Fernández AM, Mayol R. Adding support to cross-cultural emotional assessment: validation of the International Affective Picture System in a Chilean sample. Univ Psychol. 2011;10:521-33.

21. Vila J, Sánchez M, Ramírez I, Fernández MC, Cobos P, Rodríguez $\mathrm{S}$, et al. El Sistema Internacional de Imágenes Afectivas (IAPS): adaptación española. Segunda parte. Rev Psicol Gen Apl. 2001;54:635-57.

22. Eysenck HJ. Sex and personality. London: Open Books; 1976

23. Eysenck HJ, Eysenck SB. Manual of the Eysenck Personality Questionnaire (adult and junior). London: Hodder \& Stoughton; 1975.

24. Geniole SN, Carré JM, McCormick CM. State, not trait, neuroendocrine function predicts costly reactive aggression in men after social exclusion and inclusion. Biol Psychol. 2011;87:137-45. Epub 2011 Mar 4.

25. Montoya ER, Terbug D, Bos PA, van Honk J. Testosterone, cortisol, and serotonin as key regulators of social aggression: A review and theoretical perspective. Motiv Emot. 2012;36:65-73. Epub 2011 Nov 25.

26. Sánchez-Martín JR, Azurmendi A, Pascual-Sagastizabal E, Cardas J, Braza F, Braza $P$, et al. Androgen levels and anger and impulsivity measures as predictors of physical, verbal and indirect aggression in boys and girls. Psychoneuroendocrinology. 2011;36:750-60. Epub 2010 Nov 13.

27. Wilson GD. Gender differences in sexual fantasy: an evolutionary analysis. Pers Individ Dif. 1997;22:27-31.

28. Whitaker JL, Bushman BJ. "Remain Calm. Be Kind." Effects of relaxing video games on aggressive and prosocial behavior. Soc Psychol Personal Sci. 2012;3:88-92.

\section{Correspondence:}

Carlos Gantiva

University of San Buenaventura

$\mathrm{Cr} 8 \mathrm{H}$ \# 172-20

110911 - Bogotá - Colombia

Tel./Fax: +57 (1) 6671090

E-mail: cgantiva@gmail.com 